\title{
Aquatic Studies of Gable Mountain Pond
}

December 1974

Sponsored by

The Atlantic Richfield Hanford Company

Under United States Atomic Energy

Commission Contract AT(45-1)-2130 
NOTICE

This report was prepared as an account of work sponsored by the United States Government. Neither the United States nor the United States Energy Research and Development Administration, nor any of their employees, nor any of their contractors, subcontractors, or their employees, makes any warranty, express or implied, or assumes any legal liability or responsibility for the accuracy, completeness or usefulness of any information, apparatus, product or process disclosed, or represents that its use would not infringe privately owned rights.

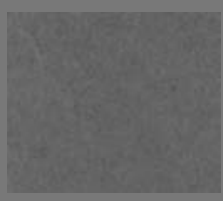

PACIFIC NORTHWEST LABORATORY

operatedby

BATTELLE

for the

U.S. ENERGY RESEARCH AND DEVELOPMENT ADMINISTRATION

Under Contract AT(45-1)-1830

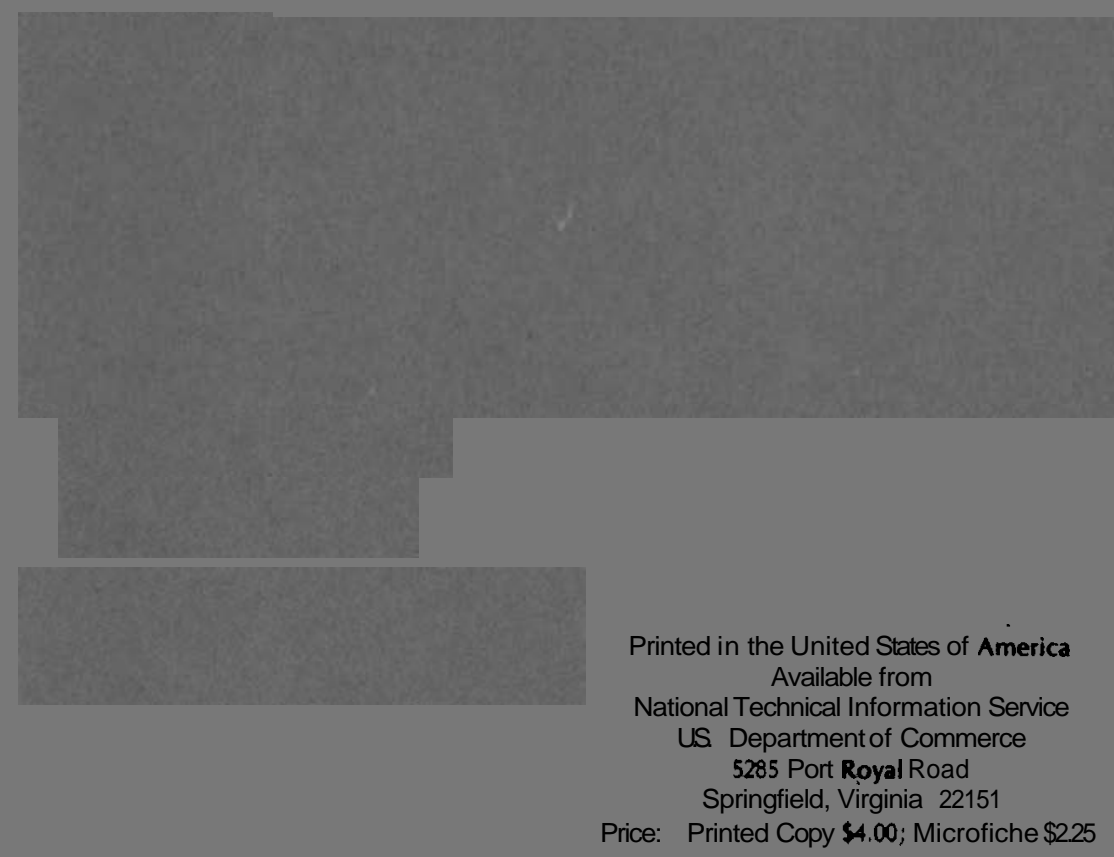

Price: Printed Copy $\$ \mathbf{4} .00$; Microfiche $\$ 2.25$ 
AQUATIC STUDIES

OF GABLE MOUNTAIN POND

by

C. E. Cushing and D. G. Watson

Ecosys tems Department

December 1974

This report was sponsored by The Atlantic Richfield Hanford Company under United States Atomic Energy Commission Contract AT(45-1)-2130

\footnotetext{
Battelle

Pacific Northwest Laboratories Richland, Washington 99352
} 


\section{ACKNOWLEDGMENTS}

This publication represents a summary report on the aquatic studies at Gable Mountain Pond from 1972-1974. We would like to acknowledge the cooperation of L. Bruns and V. Panesko of the Atlantic Richfield Hanford Company

We would also like to express our appreciation to A. J. Scott, J. M. Gurtisen, and R. D. Burdett for their capable work in the field and laboratory. The completion of this work is due largely to their efforts. 
BNWL-1884

\section{$\underline{\text { ABSTRACT }}$}

Studies of the biotic and abiotic components of the Gable Mountain Pond ecosystem were undertaken to determine if there was a potential problem for off-site transfer of radioactivity to man originating with the aquatic food web.

Most of the ${ }^{137}$ Cs in the pond is associated with the sediments which are probably the main source of ${ }^{137}$ Cs for uptake by the biota. Generally, highest concentrations of ${ }^{137}$ Cs and other radioisotopes were found in sediments in the northwest end of the pond and in the deeper areas along the long-axis of the pond. Over 90 percent of the ${ }^{137}$ Cs is in the upper 2 inches of sediment cores. Dose rates at the bottom surface of the pond ranged from about 4 to $230 \mathrm{mR} /$ day .

Native goldfish had maximum and average ${ }^{137}$ Cs concentrations of about 340 and $170 \mathrm{pCi} / \mathrm{g}$ dry wt, respectively. Algae, macrophytes, and detritus comprised the main food items of the goldfish, and the ${ }^{137}$ Cs levels in the plants were usually higher than the ${ }^{137}$ Cs concentration in the fish. Uncontaminated goldfish restricted to areas of relatively high and low levels of radioactivity attained quasi-equilibrium levels of ${ }^{137}$ Cs at different rates, time, and magnitude, with fish in the higher area accumulating nearly twice the amounts of ${ }^{137}$ Cs as fish in the lower area. The former population attained peak concentrations in about 3 months as compared to about 2 months in the latter. Both populations exhibited decreasing concentrations in winter as metabolic rates decreased.

The ${ }^{137}$ Cs concentrations of wild experimental ducks restricted to Gable Mountain Pond were approximately the same as resident coots, but significantly higher than transient wild ducks. 
Neither the goldfish nor the waterfowl inhabiting the pond attained concentrations of ${ }^{137}$ Cs exceeding acceptable limits. Sediment, however, could be a source of high concentrations of radioactivity or radioactive contamination concern if (a) the concentration of radiocontaminants increased and/or (b) the pond dries up, and the contaminated sediments become windborne. 


\title{
TABLE OF CONTENTS
}

\begin{abstract}
Page
ACKNOWLEGEMENT. . . . . . . . . . . . . . . . . . i i ABSTRACT . . . . . . . . . . . . . . . . . . v LISTOFfIGURES. . . . . . . . . . . . . . . . . . . х i

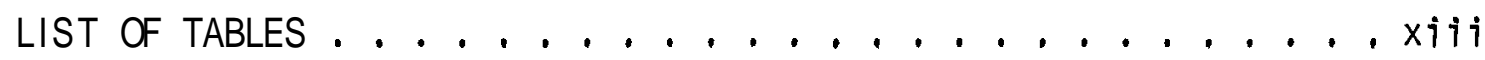
INTRODUCTION . . . . . . . . . . . . . . . . . . . . . DESCRIPTION OF STUDY AREA. . . . . . . . . . . . . . . . . . . . METHODS AND MATERIALS. . . . . . . . . . . . . . . .

Field Methods. . . . . . . . . . . . . . . . .3 Laboratory Methods. . . . . . . . . . . . . . 4 Nonradiological Analyses. . . . . . . . . . . . . Radiological Analyses. . . . . . . . . . . . . 5 RESULTS AND DISCUSSION .................. 6 Sediment Studies. . . . . . . . . . . . . . 6 Goldfish Studies. . . . . . . . . . . 10 Waterfowl Studies. . . . . . . . . . . . . CONCLUSIONS. . . . . . . . . . . . . . . . . . . . . . 21 SUGGESTED FUTURE RESEARCH. . . . . . . . . . . . . . . . . 22 REFERENCES . . . . . . . . . . . . . . . . . . . 23
\end{abstract}




\section{$\underline{\text { LIST OF FIGURES }}$}

Page

Fig. 1. Outline of Gable Mountain Pond showing sampling transects, 2 stations, and water depth.

Fig. 2. Uptake of ${ }^{137}$ Cs by uncontaminated goldfish restricted to areas of relatively high and low radioactivity (each point is the average of eight fish; curves were fitted visual ly). 


\section{LIST OF TABLES}

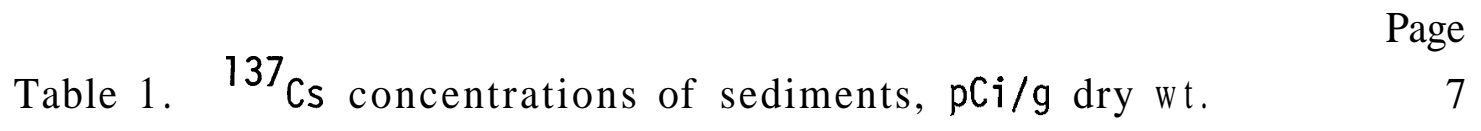

Table 2. Dose rate from sediments, mR/day. 8

Table 3. Alpha radionuclide concentrations of sediments 9

Table 4. Radionuclide concentrations in native biota. 11

Table 5. ${ }^{137}$ Cs concentrations of experimental and wild waterfowl, $\mathrm{pCi} / \mathrm{g}$ dry wt. 


\section{AQUATIC STUDIES OF GABLE MOUNTAIN POND}

\section{INTRODUCTION}

Biological studies of Gable Mountain Pond were initiated in July 1972 to identify possible vectors for the movement of radioactivity outside of the Hanford Project boundaries. The studies, therefore, were oriented toward radiation-safety. The aims of the aquatic studies were essentially twofold: (1) to determine if the pond goldfish concentrations of radionuclides are sufficiently high to be of concern in the food chain of predators, especially birds, and (2) to perform a cursory examination of radioactive levels in other biotic and abiotic components of the ecosystem. Initial sampling and analyses led to more definitive studies of the sediments, goldfish, and waterfowl. This report presents and discusses the data collected from July 1972 until May 1974.

\section{DESCRIPTION OF STUDY AREA}

Gable Mountain Pond (referred to as 216-A-25 in ARHCO waste management reports), northeast of the $200 E$ Area, is the largest pond on the Hanford Reservation which receives cooling waters that may contain low level ( $<50 \mathrm{pCi} / \mathrm{ml}$ ) radioactive liquid wastes from various processing plants (Fig. 1). It has a surface area of about 71 acres with an average depth of about 5 feet. Dissolved oxygen ranges from 8.0 to $12.6 \mathrm{ppm}$, total alkalinity from 55 to $90 \mathrm{ppm}$ and $\mathrm{pH}$ from 8.2 to over 9.0, There is little open shoreline; the edge is vegetated with peachleaf willow (Salix amygdaloides) and sandbar willow (S exigua), wild millet (Setaria lutescens), horsetail (Equisetum $\underline{\text { arvense) }}$, and sedges ( $\underline{\text { Carax }}_{\text {spp. }}$ ). Emergent aquatic vegetation near the shoreline consists of cattails (Typha latifolia) and bulrush (Scirpus spp.) 
BNWL-1884

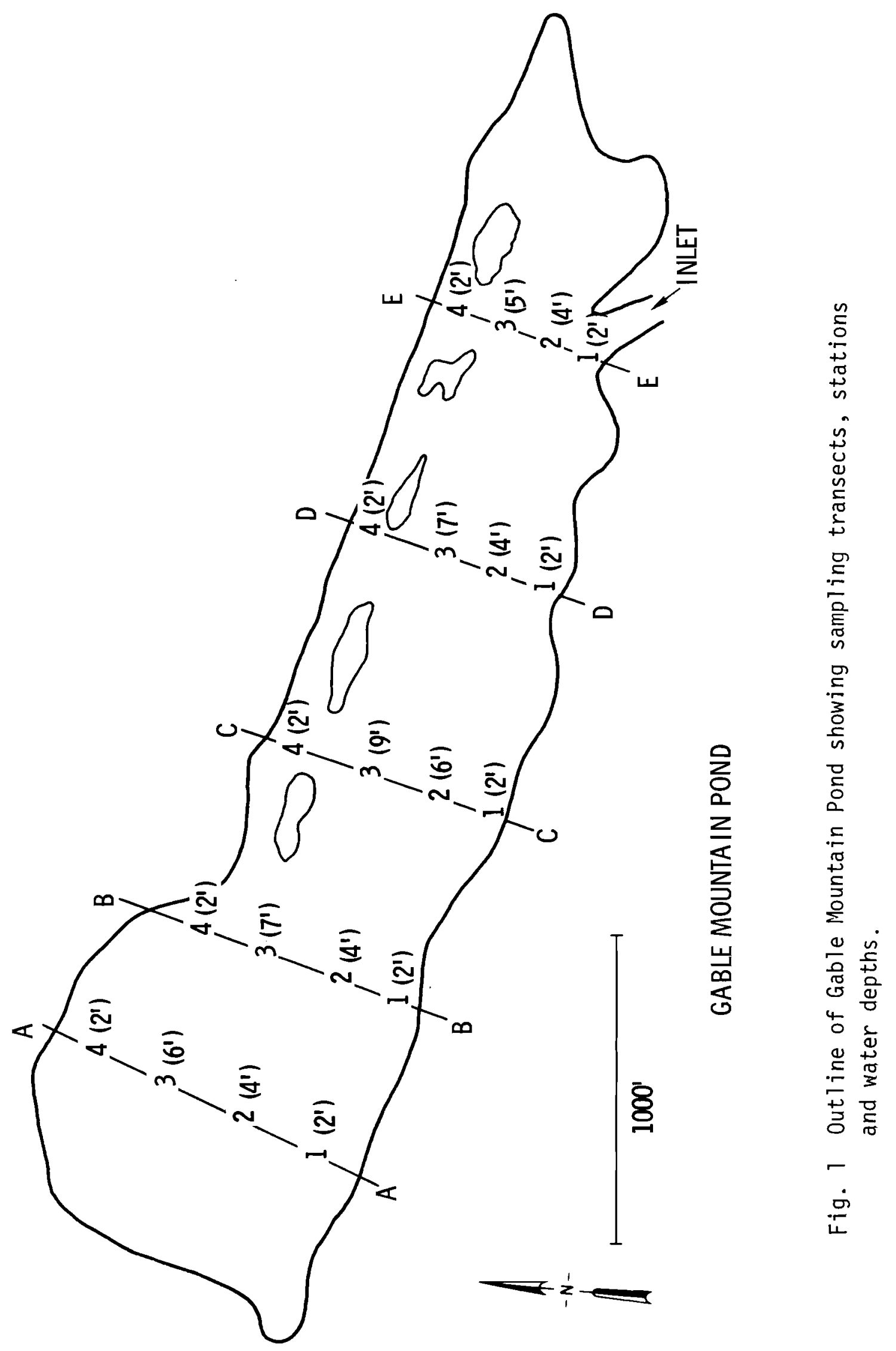


BNWL-1884

(Fitzner and Price 1973). Submerged vascular macrophytes present include pondweeds (Potamogeton filiformis and $\mathrm{P}$, richardsoni), water milfoil (Myriophyllum sp.) and waterweed (Elodea sp.). Dominant fauna include goldfish (Carassius auratus), dragonflies and damselflies (Odonata), water beetles (Coleoptera), backswimmers (Notonectidae), waterboatmen (Corixidae) water striders (Gerridae), and mayflies (Ephemeroptera).

\section{METHODS AND MATERIALS}

\section{Field Methods}

To facilitate sampling, five transects with four stations each were established across the short axis of the pond (Fig. 1). Thermoluminescent dosimeters (TLD) were placed at the mud-water interface and sediment samples were collected at these 20 stations.

Samples of $\mathrm{fi}$ lamentous algae, vascular macrophytes, molluscs, and adult and larval insects were most often collected by hand or with dredge nets and sweep nets. Native goldfish were collected with gill nets, dip nets, seines, and electrofishing gear.

Experimental, uncontaminated goldfish were restricted to areas of relatively high and low radioactivity levels in plants and sediments in $8 \mathrm{ft} \times 16 \mathrm{ft}$ pens tightly sealed with sandbags along the bottom to prevent their escape. One pen was located in the vicinity of Transect в y Sta. 3 and the other near Transect E, Sta. 3, Three-hundred fin-clipped fish were placed in each pen on May 25, 1973. Eight fish were removed from each pen at biweekly intervals and analyzed for ${ }^{137} \mathrm{Cs}$ and ${ }^{90} \mathrm{Sr}$. In the spring of 1974 when the fish showed signs of spawning, they were removed to prevent dilution of the native fish gene pool by offspring of experimental fish.

Experimental wild ducks were restricted to Gable Mountain Pond by amputation of the mantes, 'thus rendering them flightless, These and wild ducks and 
BMLL-1884

coots were collected with firearms or traps.

Sediment samples were taken with Ekman dredges and coring tubes. TLDs were used in conjunction with sediment samples to relate sediment radioactivity with dose. The TLDs were composed of LiF phosphor encapsulated in heatshrinkable plastic tubing. This phosphor has the following unique qualities which make it suitable for environmental studies: (1) a nearly linear response . over a wide range of energies $(0.03$ to $2 \mathrm{MeV})$ and exposures $\left(10^{-2}\right.$ to $\left.10^{3} \mathrm{R}\right)$, (2) near soft tissue equivalence. (3) dose rate independence, (4) responsive to both gamma and beta radiation, and (5) high retention of stored information with time (Cameron, Suntharalingam, and Kenney 1968). The heat-shrinkable tubing had a thickness of $0.254 \mathrm{~mm}$ and a density of $1.1 \mathrm{~g} / \mathrm{cm}^{3}$. The TLDs wil1 not measure alpha or soft beta radiation, but were suitable for our evaluations of ${ }^{137} \mathrm{Cs}$ dose estimates. The TLDs were fastened to the end of 1 in wooden dowels placed alongside the steel fence posts marking the 20 stations, lowered until they rested on the bottom, and tied to the posts so the dosimeters were held at the sediment-water interface.

\section{Laboratory Methods}

Nonradiological Analyses

All biological and sediment samples were processed for gravimetric determinations by drying to a constant weight at $105^{\circ} \mathrm{C}$ and then ashing at $400^{\circ} \mathrm{C}$ to obtain an ash-free dry weight (=organic matter). Goldfish gut contents were removed before drying and ashing. Gut contents were examined under a dissecting microscope to determine the goldfish's diet. Ducks and coots were thoroughly washed to remove adhering debris such as sediments and algae. Gut contents were removed and the birds were divided into two portions, the muscle and carcass (everything remaining). 
TLD's were read on a Harshaw Model 2000A thermoluminescence detector coupled to a CI Model 1491 counter system. Counts were converted to milliroentgens (mR) with a nomograph produced from readings of dosimeters that had received known doses of gamma irradiation.

\section{Radiological Analyses}

Depending upon the size of the sample, an oven-dried or ashed aliquot was submitted for gamma analysis on a RIDL Model 34-12B 400-channel analyzer, wtih a 3 in $x 3$ in NaI well crystal. Measurements for ${ }^{137} \mathrm{Cs},{ }^{95} \mathrm{Zr}$, and ${ }^{60}$ Co were obtained from the gamma scan. Recent examination of these scans, however, indicate that values for ${ }^{95} \mathrm{Zr}$ and ${ }^{60} \mathrm{Co}$ may reflect significant interference from radionuclides not included in the analytical matrix (Garland, personal communication).

Beta counts for ${ }^{90} \mathrm{Sr}$ were made following dissolving of the ashed sample with $\mathbf{H F}$ and subsequent nitrate precipitation using fuming $\mathrm{HNO}_{3}$.

Samples for total alpha analysis were dried, wet ashed with $\mathrm{HNO}_{3}$, and muffled at $400^{\circ} \mathrm{C}-450^{\circ} \mathrm{C}$. The dry ash was then redissolved with $\mathrm{HNO}_{3}$ and HF, diluted to a specific volume and an aliquot counted in a Nuclear Chicago liquid scintillation counter.

A series of eight specially selected samples was analyzed for alpha radioactivity. Samples of sediment, periphyton (a1gae), and vascular plants were oven-dried and the goldfish and snails freeze-dried prior to chemical separations generally following the procedures of Sill (1974). A11 samples, except sediments, were in solution prior to radioanalysis; sediment samples were leached to remove radioactivity and the leachate counted. Neptunium-237 was counted on a gamma detection system and the alpha 
analyses were done with a $150 \mathrm{~mm}^{2}$ surface barrier detector and a 1024channel pulse height analyzer calibrated at $5 \mathrm{KeV} / \mathrm{channel.}$

\section{RESULTS AND DISCUSSION}

\section{Sediment Studies}

Initial sampling of biota and sediments revealed that the concentration of ${ }^{137} \mathrm{Cs}$ in the sediments varied considerably in different areas of Gable Mountain Pond. A sampling program was initiated to define the spatial variation in concentration of ${ }^{137} C_{S}$ in the sediments and the associated dose rates. The transects described under METHODS AND MATERIALS were the basis for this sampling program,

Genrally, higher sediment ${ }^{137}$ Cs concentrations occurred in the deeper water, i.e., the approximate middle of each transect, and lower concentrations in the shallow water (Table 1 ). Over 90 percent of the ${ }^{137}$ Cs radioactivity in the cores was in the upper 2 inches of sediments; concentrations averaged $30150 \mathrm{pCi} / \mathrm{g}$ dry wt (range:13240-58950). Garland (personal communication) found that ${ }^{90} \mathrm{Sr}$, in contrast, was relatively higher in deeper sediments. Ion exchange is an important factor governing these distributions. These data agree with sediment dose rates measured with the TLDs at each station (Table 2); this is to be expected since the $0.254 \mathrm{~mm}$ thickness around the TLDs effectively shields out the alpha and soft beta contributions from ${ }^{90} \mathrm{Sr}$ and other radionuclides. The non-homogeneity of the radionuclide contents of the sediments precludes definitive explanation of some of the relationships suggested in Table 3. Emery, Klopfer and Weirner (1974) found that Pu concentrations in the sediments of U-Pond were randomly distributed both spatially and temporally, with no disproportionally high concentrations in any particular area. Pu concentrations in U-Pond sediments decreased 
BNWL - 1884

Table 1. ${ }^{137}$ Cs concentrations of sediments, $p C i / g$ dry wt.

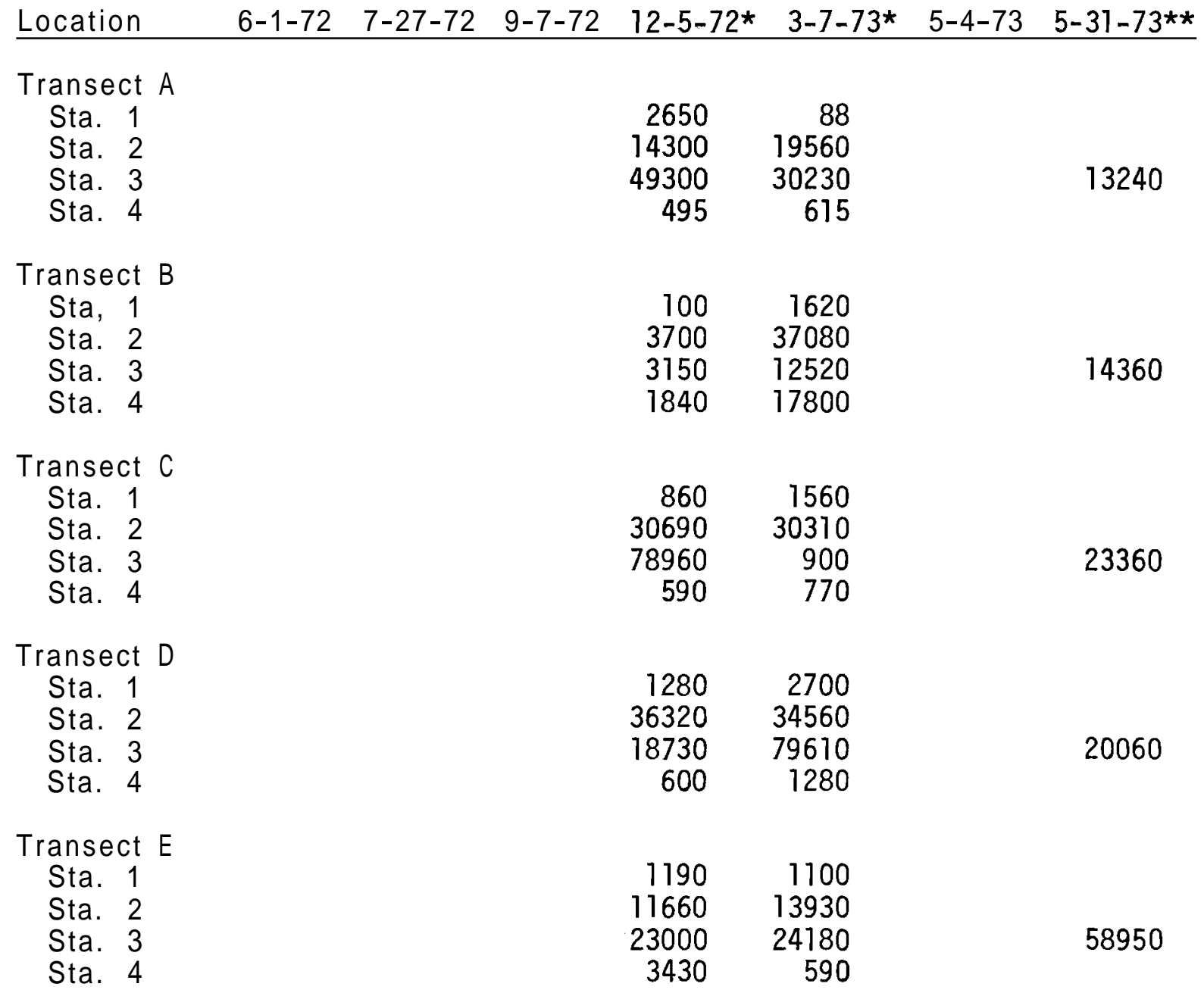

18040

$\mathrm{NW}$ end

NW end

SE end

SE end

$\begin{array}{rr}24270 & 13260 \\ 28550 & 8870 \\ 130 & 110 \\ 130 & 130\end{array}$

2050

1810

** Ekman grab samples, depth $6 "$

Upper 2" of core sample 
Table 2. Dose rate from sediments, mR/day.

\begin{tabular}{|c|c|c|c|c|c|}
\hline Location & $\begin{array}{l}12-5-72 \text { to } \\
3-7-73 \\
\text { (92 days) }\end{array}$ & $\begin{array}{l}3-7-73 \text { to } \\
10-1-73 \\
\text { (208 days) }\end{array}$ & $\begin{array}{l}12-5-72 \text { to } \\
10-1-73 \\
(300 \text { days) }\end{array}$ & $\begin{array}{l}10-1-73 \text { to } \\
1-3-74 \\
\text { (94 days) }\end{array}$ & $\begin{array}{l}\text { Water } \\
\text { Depth, ft. }\end{array}$ \\
\hline \multicolumn{6}{|c|}{ Transect A } \\
\hline Sta. 1 & 4.9 & 6,4 & & 8.8 & 2 \\
\hline Sta. 2 & 43.8 & 40.8 & & 28.2 & 4 \\
\hline Sta. 3 & 39.7 & 58.7 & & 94.7 & 6 \\
\hline Sta. 4 & 4.0 & 9.2 & & 8.7 & 2 \\
\hline \multicolumn{6}{|c|}{ Transect $B$} \\
\hline Sta. 1 & 1.8 & 3.0 & & 6.8 & 2 \\
\hline Sta. 2 & 13.6 & 53.9 & & 34.5 & 4 \\
\hline Sta. 3 & 27.6 & 53.9 & & 72.3 & 7 \\
\hline Sta. 4 & 9.0 & 21.6 & & 13.3 & 2 \\
\hline \multicolumn{6}{|c|}{ Transect $\mathrm{C}$} \\
\hline Sta. 1 & 7.1 & 20.7 & & 21.3 & 2 \\
\hline Sta. 2 & 51.0 & 100.0 & & 83.0 & 6 \\
\hline Sta. 3 & 228.5 & 136.9 & & lost & 9 \\
\hline Sta. 4 & 6.4 & 6.3 & & 9.8 & 2 \\
\hline \multicolumn{6}{|c|}{ Transect $D$} \\
\hline Sta. 1 & 20.9 & 20.8 & 20.1 & 22.3 & 2 \\
\hline Sta. 2 & 130.4 & 82.5 & 89.7 & 96.8 & 4 \\
\hline Sta. 3 & 127.0 & 125.5 & 124.6 & 216.0 & 7 \\
\hline Sta. 4 & 3.6 & 5.1 & 4.0 & 8.1 & 2 \\
\hline \multicolumn{6}{|c|}{ Transect $\mathrm{E}$} \\
\hline Sta. 1 & 21.2 & 23.5 & 23.3 & 13.3 & 2 \\
\hline Sta. 2 & 10.9 & 9.7 & 9.5 & 16.0 & 4 \\
\hline Sta. 3 & 81.5 & 53.4 & 57.8 & 72.3 & 5 \\
\hline Sta. 4 & 4.8 & 3.9 & 4.2 & lost & 2 \\
\hline
\end{tabular}


Table 3. Alpha radionuclide concentrations of sediments.

\begin{tabular}{|c|c|c|c|c|c|c|}
\hline \multirow[b]{2}{*}{ Location } & \multirow[b]{2}{*}{ Date } & \multicolumn{5}{|c|}{$\mathrm{pCi} / \mathrm{g}$ dry wt } \\
\hline & & $\begin{array}{l}\text { Total } \\
\text { alpha }\end{array}$ & ${ }^{239} \mathrm{Pu}$ & ${ }^{238} \mathrm{Pu}$ & $239+240 \mathrm{Pu}$ & ${ }^{241} \mathrm{Am}$ \\
\hline-- & $6-01-72$ & 130.6 & 3.2 & & & \\
\hline $\mathrm{NW}$ end & $7-27-72$ & 572.4 & 7.2 & & & \\
\hline NW end & $7-27-72$ & 573.7 & 8.0 & & & \\
\hline SE end & $7-27-72$ & 3.7 & 0.2 & & & \\
\hline SE end & $7-27-72$ & 3.8 & 0.5 & & & \\
\hline NW end & $9-07-72$ & 179.6 & 1.3 & & & \\
\hline NW end & $9-07-72$ & 184.9 & 1.3 & & & \\
\hline SE end & $9-07-72$ & $<0.3$ & 0.3 & & & \\
\hline SE end & $9-07-72$ & $<0.5$ & 0.5 & & & \\
\hline $\begin{aligned} \text { Trans. } & \text { B } \\
\text { Sta. } & 2\end{aligned}$ & $5-29-73$ & & & 0.0005 & 0.011 & 0.009 \\
\hline $\begin{aligned} \text { Trans. } & C \\
\text { Sta. } & 2\end{aligned}$ & $5-29-73$ & & & 0.088 & 1.5 & 1.4 \\
\hline
\end{tabular}


BNWL-1884

with depth down to $10 \mathrm{~cm}$.

Alpha emitting radionuclides in sediments were higher in the northwest end of Gable Mountain Pond than in the southeast end (Table 3). Maximum concentrations of ${ }^{239} \mathrm{Pu}$ and ${ }^{141} \mathrm{Am}$ were 8.0 and $1.4 \mathrm{pCi} / \mathrm{g}$ dry wt, respectively.

\section{Goldfish Studies}

The objectives of these studies were to determine the levels of ${ }^{137} \mathrm{Cs}$ in the native goldfish population and to determine if they represented a potentially significant source for off-site distribution of radioactivity via food webs leading to man. Two investigative approaches were used:

(1) the determination of concentrations of radioactivity in the native fish and their food items, and (2) introduction and restriction of uncontaminated experimental goldfish to areas of differing ambient ${ }^{137}$ Cs levels to study the rate and magnitude of uptake.

Table 4 presents the concentrations of various radionuclides in captive and native goldfish and their food items, The highest concentration was $1660 \mathrm{pCi}{ }^{137} \mathrm{Cs} / \mathrm{g}$ dry $w \mathrm{t}$, found in a fish less than $40 \mathrm{~mm}$ long collected in the northwest end of the pond on March 28, 1973. This fish, however, was analyzed without removing the gut contents; the high count is likely related to the generally higher levels of ${ }^{137} \mathrm{Cs}$ found in the food organisms of the fish. Another fish collected at the same time and place contained about $340 \mathrm{pCi} / \mathrm{g}$ dry wt. This $\mathrm{fish}$ was $100 \mathrm{~mm}$ in length and gut contents were removed before radioanalysis. Cesiurn-137 concentrations for eight other specimens averaged about $170 \mathrm{pCi} / \mathrm{g}$ dry wt. Six small fish $(<40 \mathrm{~mm})$ collected on June 22, 1972, contained an average total alpha concentration of $5.2 \mathrm{pCi} / \mathrm{g}$ dry wt, For comparison, carp, a closely related species with similar food habits, collected from White Oak Lake, Oak Ridge National Laboratory, contained 
Table 4. Radionuclide concentrations in native biota.

$\mathrm{Ni} / \mathrm{g}$ dry $w \mathrm{t}$

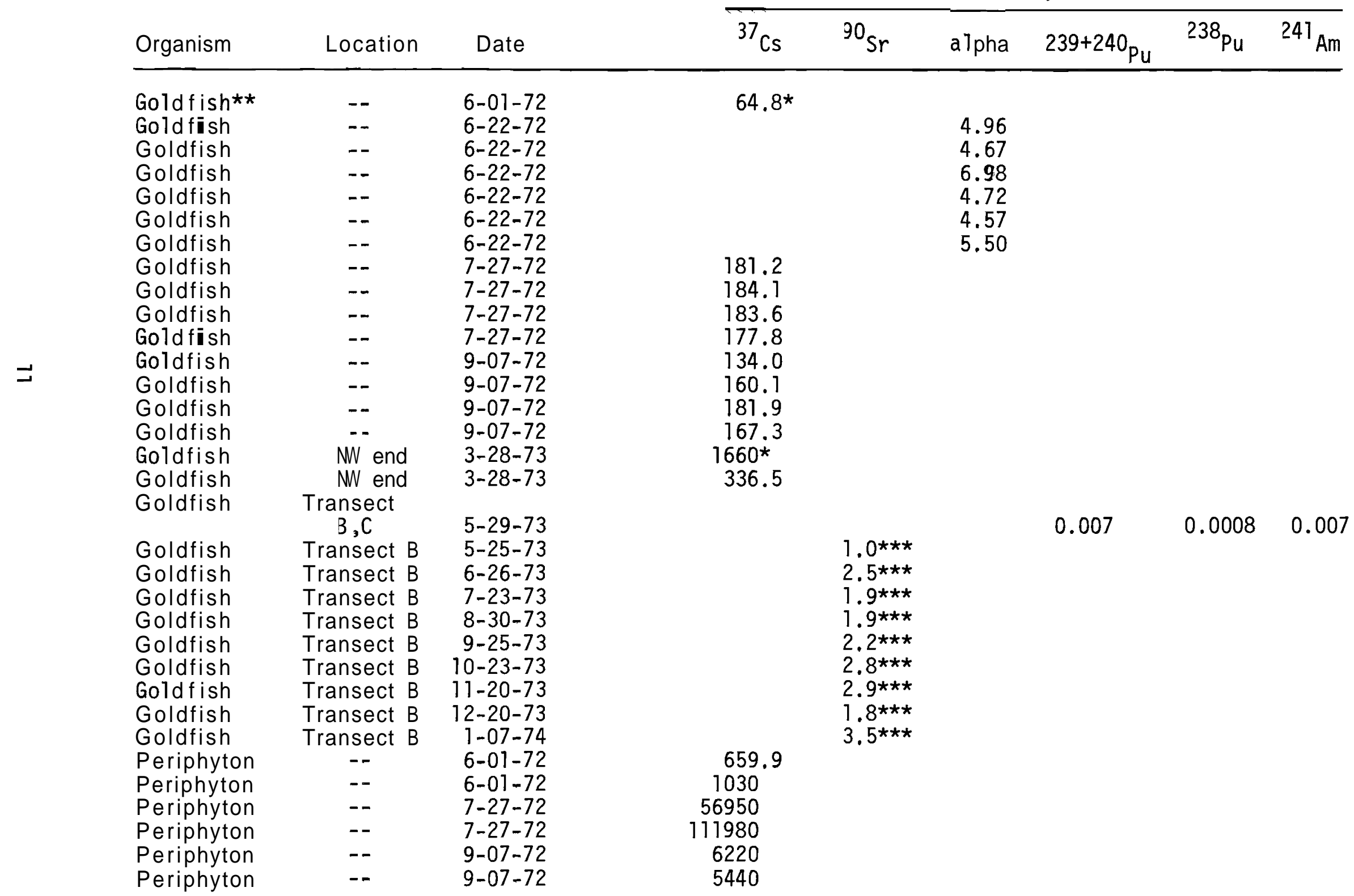


Table 4. (Continued)

$\mathrm{pCi} / \mathrm{g}$ dry wt

\begin{tabular}{|c|c|c|c|c|c|c|c|c|}
\hline \multirow[b]{2}{*}{ Organism } & \multirow[b]{2}{*}{ Location } & \multirow[b]{2}{*}{ Date } & \\
\hline & & & ${ }^{137} \mathrm{Cs}$ & ${ }^{90} \mathrm{Sr}$ & $\begin{array}{l}\text { Total } \\
\text { alpha } \\
\end{array}$ & $239+240 \mathrm{Pu}$ & ${ }^{238} \mathrm{Pu}$ & ${ }^{241} \mathrm{Am}$ \\
\hline \multicolumn{9}{|l|}{ Ani soptera } \\
\hline \multicolumn{9}{|l|}{ Zygoptera } \\
\hline adults & --- & $6-01-72$ & $10.3 \#$ & & & & & \\
\hline adults & -- & $7=27-72$ & 7. $3 \#$ & & & & & \\
\hline adults &.- & $7-27-72$ & $11.4 \#$ & & & & & \\
\hline \multicolumn{9}{|l|}{ Zygoptera } \\
\hline nymphs & NW end & $3-28-73$ & 118.0 & & & & & \\
\hline Coleoptera & --- & $6-01-72$ & 216.2 & & & & & \\
\hline Coleoptera & -- & $6-01-72$ & 278.2 & & & & & \\
\hline Coleoptera & -- & $7-27-72$ & 67.7 & & & & & \\
\hline Coleoptera & -- & $7-27-72$ & 58.3 & & & & & \\
\hline Coleoptera & SE end & $3-28-73$ & 3.1 & & & & & \\
\hline Colẹoptera & NW end & $3-28-73$ & 16.2 & & & & & \\
\hline Corixídae & -- & $9-07-72$ & 138.0 & & & & & \\
\hline Corixidae & SE end & $3-28-73$ & 16.9 & & & & & \\
\hline Corixidae & NW end & $3-28-73$ & 50.8 & & & & & \\
\hline Notonecti dae & SE end & $3-28-73$ & 4.8 & & & & & \\
\hline Gerridae & SE end & $3-28-73$ & 4.9 & & & & & \\
\hline \multicolumn{9}{|l|}{ Ephemeroptera } \\
\hline nymphs & SE end & $3-28-73$ & 50.6 & & & & & \\
\hline nymphs & NW end & $3-28-73$ & 156.8 & & & & & \\
\hline
\end{tabular}

** Gut contents included

*** All data for goldfish are analyses of a single fish

*** Experimental fish

\# $\mathrm{pC} \dot{\mathrm{j}} / \mathrm{g}$ wet $\mathrm{wt}$ 
an average concentratlon of $24.2 \mathrm{pCi}{ }^{137} \mathrm{Cs} / \mathrm{g}$ dry wt (Kevern and Griffith 1965). White Oak Lake receives low-level aqueous wastes from the processing plants at Oak Ridge National Laboratory.

Experimental goldfish restricted to the area of high radioactivity were also analyzed for ${ }^{90} \mathrm{Sr}$. Strontium-90 measurements were made on the fish from monthly samples which contained the highest ${ }^{137}$ Cs concentrations. The average concentration in these nine fish was $2.3 \mathrm{pCi} / \mathrm{g}$ dry wt (range: $1.0-3.5) ;{ }^{90} \mathrm{Sr}$ concentrations did not appear to increase with time.

Concentrations of ${ }^{137}$ Cs in periphyton (mainly the alga Cladophora), one of the main food items of the goldfish, varied within the pond depending upon location, and averaged about $18900 \mathrm{pCi} / \mathrm{g}$ dry wt (Table 4). The higher concentration in the periphyton indicates that the goldfish are not concentrating ${ }^{137}$ Cs to levels higher than their food. Concentrations of alpha radionucl ides were less than $1 \mathrm{pC} i / g$ dry wt (Table 4 ),

Potamogeton filiformis, another prominent food item in the goldfish diet, had average ${ }^{137}$ Cs concentrations of about $1640 \mathrm{pCi} / \mathrm{g}$ dry wt. This is also higher than the average ${ }^{137}$ Cs concentratlon of the goldfish. As with the periphyton, concentrations of alpha radionuclides in $\mathrm{D}$ filiformis were less than $1 \mathrm{pCi} / \mathrm{g}$ dry wt.

The above data indicate that the goldfish do not appear to be concentrating ${ }^{137} \mathrm{Cs}$ in amounts greater than their primary food sources. In contrast, Pendleton and Hanson (1958) and Pendleton (1965) reported higher levels of ${ }^{137}$ Cs in carp than in algae from a Hanford waste pond receiving mixed fission elements. Their data a7so resulted in higher concentration factors $\left({ }^{137} \mathrm{Cs} / \mathrm{g}\right.$ wet wt: ${ }^{137} \mathrm{Cs} / \mathrm{ml}$ water) for carp than for algae and macrophytes. This would indicate that the carp concentrated the ${ }^{137}$ Cs in these food items. Nelson, 
Kevern, and Griffith (1967) state that there appears to be no general trophic level increase of Cs in aquatic environments and our results would agree with this observation. Our sampling was insufficient to establish a good correlation between ${ }^{137}$ Cs concentration in fish and their food.

The second approach of the goldfish studies was to determine the rate and magnitude of ${ }^{137}$ Cs uptake by uncontaminated fish as described in the METHODS AND MATERIALS section. Native fish were collected during the winter to compare with the experimental populations; results are shown in Fig. 2.

Fish in the area of higher radioactivity approached equilibrium concentrations of ${ }^{137}$ Cs within three months (Fig. 2). Concentrations of ${ }^{137}$ Cs in the fish over the less radioactive sediments reached quasi-equilibrium levels about a month earlier and at levels of about one-half of those over the area of higher radioactivity. Both populations showed evidence of declining concentrations after October and November. This was probably related to the decreased metabolic rates as water temperatures decreased and feeding slowed. Differing assimilation rates and ${ }^{137}$ Cs concentration of the fish's food items may also be involved in these observations. Kevern, Griffith, and Grizzard (1964), studying carp from White Oak Lake in the laboratory, found that ${ }^{134} \mathrm{Cs}$ was lost faster as water temperatures and metabolic rates increased. These fish, however, were given a single dose of ${ }^{134} \mathrm{Cs}$ tagged detritus as food and held in uncontaminated water.

The ${ }^{137}$ Cs levels in the fish in the low level pen were similar to those in free-ranging native fish. Three native fish, evidently entrapped when the pen was placed in the pond, were collected on January 7,1974 , in the high level pen, Their average concentration of ${ }^{137} \mathrm{Cs}$ was about $54.0 \mathrm{pCi} / \mathrm{g}$ dry wt, or approximately 
BNWL-1884

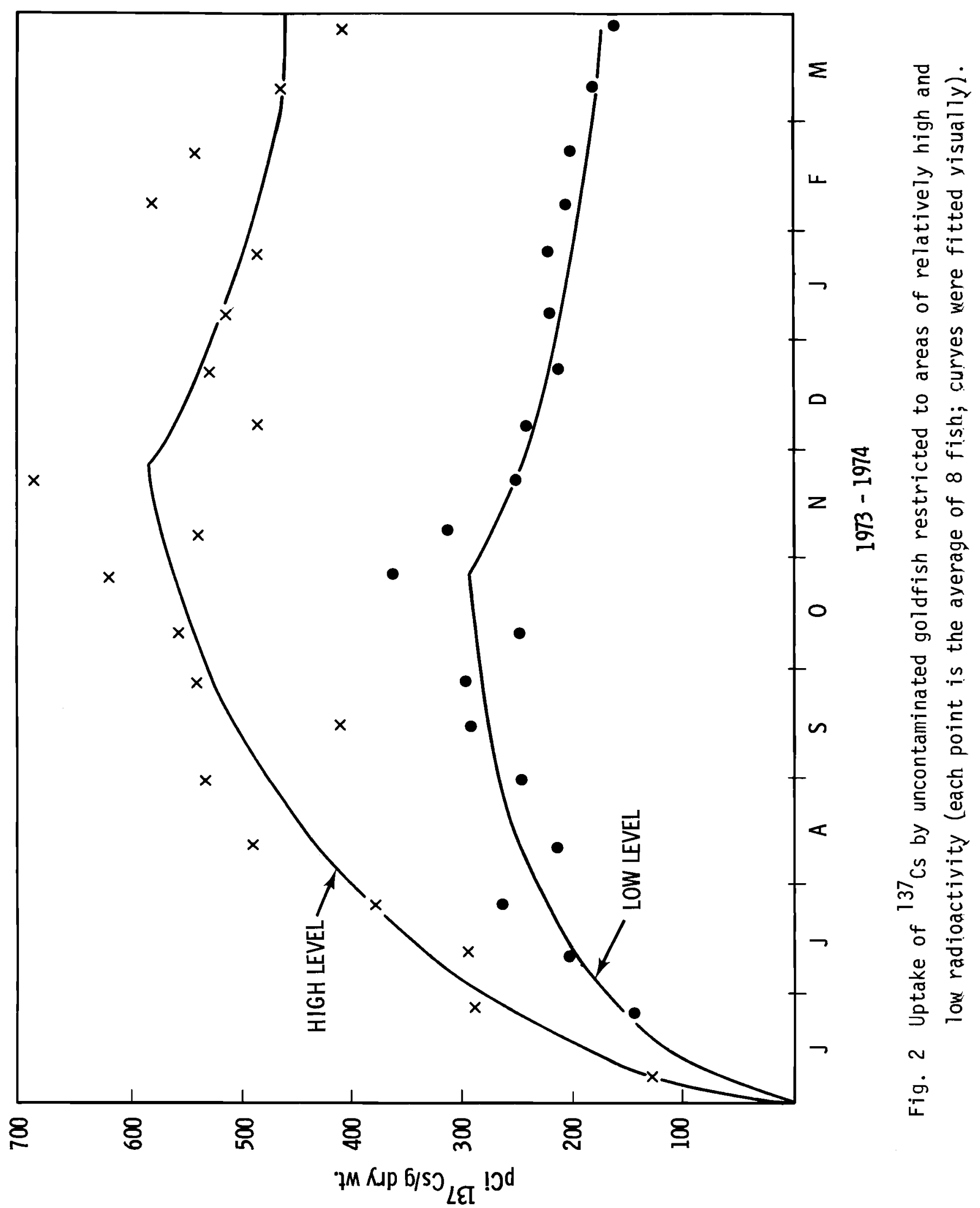


the same as that of the experimental fish in this pen and higher than freeranging native fish. This further supports the conclusion that ${ }^{137} \mathrm{Cs}$ concentrations were directly related to the concentration of this radionuclide in sediments and food.

Results from this initial, limited study suggest that neither native, free-ranging goldfish nor fish restricted to areas of relatively high ${ }^{137} \mathrm{Cs}$ levels in food and sediments accumulated concentrations of ${ }^{137}$ Cs which would be of concern in known food webs leading to man. However, more detailed research is needed to substantiate these conclusions.

\section{Waterfowl_Studies}

Potential vectors, for off-site transfer of radioactivity from Gable Mountain Pond to man are waterfowl which feed on the pond and are shot off-site and consumed. Waterfowl are routinely sampled from the Hanford radioactive waste ponds and analyzed by the Battelle Occupational and Environmental Safety Department, Occasionally a duck with unusually high concentrations of radioactivity is collected. Since it is unknown where these ducks accumulated the radioactivity, it was decided to ascertain whether ducks restricted to Gable Montain Pond could attain these high concentrations.

Wild ducks, obtained from the Puget Sound area, were restricted to Gable Mountain Pond where they obtained all of their food. This, theoretically, should provide an estimate of the "maximum concentration" attainable by birds permanently resident on the pond.

One-hundred wild mallards were restricted to Gable Mountain Pond as described under MEIHODS AND MATERIALS. The birds were placed on the pond on August 8,1973 . Table 5 presents the concentrations of ${ }^{137} \mathrm{Cs}$ in the experimental 
Table 5. ${ }^{137} \mathrm{Cs}$ concentrations of experimental and wild waterfowl, $\mathrm{pCi} / \mathrm{g}$ dry wt.

Experimental ducks*

\begin{tabular}{lrr}
\hline Date & muscle & carcass \\
\hline $9-13-73$ & 266.5 & 81.1 \\
$9-13-73$ & 522.2 & 148.0 \\
$9-13-73$ & 225.5 & 191.2 \\
$9-13-73$ & $\bar{x}=\frac{109.6}{281.0}$ & 51.5 \\
& & 118.0
\end{tabular}

$\begin{array}{lll}10-23-73 & 414.4 & 217.8\end{array}$

$11-5-73$

$11-5-73$
Wild ducks

\begin{tabular}{lrr}
\hline Date & muscle & carcass \\
\hline $11-05-73$ & 4.6 & 0.8 \\
$11-06-73$ & 174.8 & 78.9 \\
$11-06-73$ & 25.2 & 37.6 \\
$11-06-73$ & 3.2 & 3.5 \\
$11-06-73$ & 188.4 & 74.5 \\
& $\bar{x}=\frac{79.2}{40.3}$
\end{tabular}

$$
\begin{aligned}
& \begin{array}{rrr}
1-03-74 & 7.3 & 1.1 \\
1-03-74 & 107.2 & 17.2
\end{array} \\
& \begin{array}{lll}
1-03-74 & 65.4 & 10.9
\end{array} \\
& \begin{array}{lll}
1-03-74 & 36.5 & 10.0
\end{array} \\
& \text { 1-03-74 } \\
& \bar{x}=\begin{array}{rr}
4.3 & 1.2 \\
44.1 & 8.1
\end{array}
\end{aligned}
$$

\begin{tabular}{|c|c|c|}
\hline Date & muscle & carcass \\
\hline $\begin{array}{l}9-13-73 \\
9-13-73\end{array}$ & $\begin{array}{r}534.7 \\
\bar{x}=\frac{216.2}{375.5}\end{array}$ & $\begin{array}{r}216.6 \\
83.2 \\
149.9\end{array}$ \\
\hline $\begin{array}{l}10-09-73 \\
10-09-73 \\
10-09-73 \\
10-09-73\end{array}$ & $\begin{array}{r}1154.6 \\
12.3 \\
442.7 \\
\bar{x}=539.2 \\
537.2\end{array}$ & $\begin{array}{r}868.0 \\
29.6 \\
115.6 \\
592.4 \\
401.4\end{array}$ \\
\hline $\begin{array}{l}1-03-74 \\
1-03-74 \\
1-03-74 \\
1-03-74 \\
1-03-74 \\
1-03-74\end{array}$ & $\begin{array}{r}767.4 \\
446.4 \\
1220.1 \\
458.9 \\
914.1 \\
\bar{x}=\frac{897.0}{784.0}\end{array}$ & $\begin{array}{l}276.0 \\
145.5 \\
616.7 \\
172.3 \\
262.4 \\
192.1 \\
277.5\end{array}$ \\
\hline
\end{tabular}

Coots

Released August 8, 1973 
ducks and wild ducks and coots, High mortality of the experimental ducks, and non-avai lability of wild ducks, except during migration, 1 imited the data collected. The few results obtained, however, showed an obvious difference in the ${ }^{137}$ Cs concentrations in the two duck populations and relatively high concentrations in wild coots. The average concentration of ${ }^{137}$ Cs in muscle tissue of restricted ducks was about $290 \mathrm{pCi} / \mathrm{g}$ dry wt; the maximum for a single bird was $522 \mathrm{pCi} / \mathrm{g}$ dry wt. Coots, which tend to have more continuous residency on the pond than other waterfowl, had an average concentration during the same time period, of about $480 \mathrm{pCi}{ }^{137} \mathrm{Cs} / \mathrm{g}$ dry wt in the muscle. These concentrations were equal to or greater than those in the experimental ducks. Cesium-137 is known to concentrate in muscle tissue and concentrations were always higher in the muscle than in the remainder of the carcass, except for wild ducks that had low ${ }^{137}$ Cs concentrations.

Loss of many of the experimental waterfowl to predators reduced the number of observations on the experimental population. However, the results obtained showed that the birds restricted to or resident on the pond accumulated ${ }^{137}$ Cs concentrations higher than transient ducks.

It is of interest to compare the concentrations of ${ }^{137} \mathrm{Cs}$ found in the experimental and transient ducks with data from other sources. Nees and Corley (1974) reported the ${ }^{137}$ Cs concentrations of wild ducks shot within three miles of the Columbia River. Thirty-eight ducks were analyzed, and the maximum ${ }^{137} \mathrm{Cs}$ concentration in the muscle was $0.41 \mathrm{pCi} / \mathrm{g}$ wet $\mathrm{wt}(1.05 \mathrm{pCi} / \mathrm{g}$ dry wt). Only 8 of the 38 birds had concentrations above detectable limits and the average for a 11 birds was below detectable limits. These values are significantly below our measurements of ${ }^{137} \mathrm{Cs}$ in the muscle tissue of the transient 
ducks from Gable Mountain Pond (Table 5), and indicate that ${ }^{137}$ Cs is accumulated quite rapidly by birds using this pond. Wilson and Essig (1970) presented ${ }^{137}$ Cs concentrations of ducks collected from the waste swamps on the Hanford Reservation, Yalues for seven ducks ranged from 70 to $420 \mathrm{pCi}{ }^{137} \mathrm{Cs} / \mathrm{g}$ wet wt (180-1080 pCi ${ }^{137} \mathrm{Cs} / \mathrm{g}$ dry wt) with an average of $300 \mathrm{pCi} / \mathrm{g}$ wet $w \mathrm{t}\left(771 \mathrm{pCi}{ }^{137} \mathrm{Cs} / \mathrm{g}\right.$ dry wt). These concentrations exceed those of both the experimental and transient ducks. Wilson and Essig (1970) further state that consumption of one-half pound of the bird containing the maximum ${ }^{137} \mathrm{Cs}$ concentration (420 pCi/g wet wt) would result in an estimated radiation dose to man of 8 mrem for the skeletal bone and 6 mrem for the whole body. This is about 1 percent of the annual acceptable dose to individuals of the population at large. If a person ingested 10 one-half pound meals of muscle tissue from the restricted duck with the highest concentration of ${ }^{137} \mathrm{Cs}$ in our study (520 pCi/g dry wt), this would produce a radiation dose of about 28 mrem for the whole body or about 6 percent of the annual acceptable dose to individuals of the population at large. The average ${ }^{137}$ Cs concentration in muscle of transient ducks was about one-fifth of that in the restricted ducks (Table 5). In the unlikely event that a person consumed 10 one-half pound meals of transient birds, the resulting dose to the whole body would be less than 1 percent of the annual acceptable dose, It therefore seems likely that ducks residing on Gable Mountain Pond for up to 3 months are not a significant source of radiation exposure to man. The average ${ }^{137}$ Cs concentration in the muscle tissue of the transient ducks collected in our study was about $62 \mathrm{pCi} / \mathrm{g} d r y$ wt, approximately an order of magnitude less than the average of $300 \mathrm{pCi} / \mathrm{g}$ wet w t (771 pCi/g dry wt) for wild ducks reported by Wilson and Essig (1970). No explanation for this is apparent; the transient nature of these birds makes comparison tenuous, at best. 
BNWL-1884

\section{CONCLUSIONS}

The ${ }^{137}$ Cs associated with the sediments comprises the largest single pool of radionuclides among the biotic and abiotic components of Gable Mountain Pond. As such, it is the main source of this isotope for cycling in the food web of this ecosystem. Experiments and analyses herein reported, however, suggest that the biota do not accumulate sufficient ${ }^{137} \mathrm{Cs}$ to be of concern in off-site transfer to man. The sediments can possibly be of concern in the future if the pond dries up, and sediments, containing up to $58,000 \mathrm{pCi}{ }^{137} \mathrm{Cs} / \mathrm{g}$ dry wt, become windborne.

Cesium-137 concentrations in native goldfish are not high enough to result in significant food chain transfer to man. The principal route of transfer from goldfish to man would be via fish-eating birds. The merganser, which inhabits Gable Mountain Pond, is classified as a game species; however, it is believed that not enough of these birds are consumed to constitute a problem. Based on the dose calculations of Wilson and Essig (1970), consumption of 10 one-half pound meals of the duck with highest ${ }^{137} \mathrm{Cs}$ concentration found in this study would result in about 6 percent of the annual acceptable dose to individuals of the population at large. Since this is highly unlikely and since transient birds contained, on the average, about one-fifth of the ${ }^{137}$ Cs concentration as the restricted ducks, the chance of sufficient intake of ${ }^{137}$ Cs to produce significant doses to man is remote. The average ${ }^{137}$ Cs concentration in coot muscle was about twice the concentration of our restricted ducks but still only about one-half that of the duck containing $420 \mathrm{pCi} / \mathrm{g}$ wet wt (1080 pCi/g dry wt) reported by Wilson and Essig (1970). The highest single concentration found in coot muscle (1220 pCi ${ }^{137}$ Cs/g dry wt) was comparable to that of the above duck. However, even 
BNML-1884

though coots can be hunted and eaten, they probably do not constitute a serious problem for off-site transfer of ${ }^{137}$ Cs.

These studies suggest that waste ponds receiving the quantities of lowlevel wastes presently discharged into Gable Mountain Pond will not result in levels of ${ }^{137}$ Cs in biota which would constitute a problem if consumed by man. Cesium-137 associated with the sediments, however, could be of concern if concentrations increased and/or the sediments become airborne.

\section{SUGGESTED FUTURE RESEARCH}

The investigations described above have provided useful ecological and waste management information. These studies have suggested further work to either investigate the above results in greater detail or to examine other features of the Gable Mountain Pond ecosystem. These include:

1. A more thorough study of the radionuclide burden of coots.

2. A detailed and longer study of penned and transient ducks would be desirable to better define the maximum burdens of ${ }^{137} \mathrm{Cs}$ that could be assimilated by ducks.

3. Penned goldfish studies which include transfer of the fish to West Pond to examine retention kinetics of ${ }^{137} \mathrm{Cs}$.

4. Diet analysis of goldfish, coots, and ducks to more completely understand the differential accuniulation of radioactivity. 


\section{REFERENCES}

Cameron, J. R., N. Suntharalingam, and G. N. Kenney. 1968.

Thermoluninescent Dosimetry, University of Wisconsin Press, Madison. $232 \mathrm{pp}$.

Emery, R. M., D. C. Klopfer, and W. C. Weimer. 1974. The Ecological Behavior of Plutonium and Americium in a Freshwater Ecosystem: Phase I-Limnological Characterization and Isotopic Distribution, BNWL-1867, Battelle, Pacific Northwest Laboratories, Richland, WA. $73 \mathrm{pp}$.

Fitzner, R. E. and K. R. Price. 1973. The Use of Hanford Waste Ponds by Waterfowl and Other Birds. BNWL-1738, Battelle, Pacific Northwest Laboratories, Richland, WA. 25 pp. + appendices.

Garland, T. BW Ecosystems Dept. Personal communication.

Kevern, N. R. and N. A. Griffith. 1965. Feeding rate and metabolism of carp in White Oak Lake, pp. 86-87. In: Health Phys. Div. Ann. Progr. Rept., ORNL-3849, Oak Ridge National Laboratory, TN.

Kevern, N. R., N. A. Griffith, and T. Grizzard. 1964. Biological halfI if e of ${ }^{134}$ Cs in carp and two aquatic insects, 101-102. In: Health Phys. Div. Ann. Progr. Rept., ORNL-3697, Oak Ridge National Laboratory, TN.

Nees, W. L. and J. P. Corley. 1974. Environmental Surveillance at Hanford for CY-1973. BNWL-1811, Battelle, Pacific Northwest Laboratories, Richland, WA., 56 pp. + appendices.

Nelson, D. J., N. R. Kevern, and N. A. Griffith. 1967. Cesium and potassium in aquatic food chains, pp.97-98. In: Health Phys. Div. Ann. Progr. Rept., ORNL-4168, Oak Ridge National Laboratories, TN.

Pendleton, R. C. and W. C. Hanson. 1958. Absorption of cesium-137 by components of an aquatic community. In: Proc. 2nd $\mathrm{WN}$ Int. Conf. on the Peaceful Uses of Atomic Energy. Vol. 18, pp. 419-422, United Nations, Geneva. 
Pendleton, R. C. 1965. Accumulation of cesium-137 through the aquatic food web, pp.355-363. In: Biological Problems in Water Pollution. U.S. Dept. Health Education and Welfare, Cincinnati, Ohio.

Si11, C. W. , K. W. Puphal, and F. D. Hindman. 1974. Simultaneous Determination of Alpha-mitting Nuclides of Radium through Californium in Soil. Chem 46:1725-1737.

Wilson, C. B. and T. H. Essig (eds.). 1970. Evaluation of Radiological Conditions in the Vicinity of Hanford for 1969., BNWL-1505, Battelle, Pacific Northwest Laboratories, Richland, WA 73 pp. 
BNML-1884

Special Distribution

Category UC-48

\section{DISTRIBUTION}

No. of

$\underline{\text { Copies }}$

ERDA Chicago Patent Group

U.S. Energy Research and

Development Administration

9800 South Cass Avenue

Argonne, Illinois 60439

A. A. Churm

27

巴DDA Technical Infomation Center

Division of Production and Materials Management

U.S. Eneray Research and

Development Administration

Washington, D. C. 20545

D. E. Saire

6

Biomedical and Enviromental Research

U.S. Eneray Research and

Development Administration

Washington, D.C. 20545
W. Forster
R. E. Franklin
J. L. Liverman
G. W. Saunders
C. L. Osterberg
R. L. Watters

Research 0 ffice U. S. Nuclear Regulatory Commission

Washington, D.C. 20555

J. J. Davis

Argonne National Laboratory 9800 South Cass Ave.

Argonne, $11 \mathrm{I}$ inois 60439

\section{Librarian}

Brookhaven National Laboratory

Research Library, Reference Section

Upton, Long Island, New York 11973 
1 E. I _ duPont de Nemours Co. Savannah River Laboratory Aiken, So. Carolina 29801

R. S. Harvey

1 Savannah River Ecology Laboratory

Drawer "E"

Aiken, So. Carolina 29801

M. H. Smith

1

Lawrence Radiation Laboratory

Lawrence Livermore Laboratory

Technical Information Dept. , L-3

P.O. Box 808

Livermore, Ca. 94550

$1 \quad$ Los Alamos Scientific Laboratory

P.0. Box 1663

Los Alamos, New Mexico 87544

W. C. Hanson

1 Oak Ridge National Laboratory Environmental Sciences Division

Oak Ridge, Tennessee 37830

D. J. Nelson

No. of

Copies

ONSITE-HANFORD

2

ERDA-Richland Operations Office

P. F. X. Dunnigan, Jr./B. J. Melton

J. L. Rhodes/D. M. Smith

38 Atlantic Richfield Hanford Company
J. D. Anderson
W. M. Harty
H. Babad
0. S. Hill
G. E. Backman
H. H. Hopkins, Jr.
D. J. Brown
R. E. Isaacson (5)
L. E. Bruns
C. W. Malody
G. Burton, Jr.
D. Grudin
H. L. Maxfield
G. L. Hanson
T. R. McKenzie
M. K. Harmon
B. J. McMurray
D. C. Nelson 
BNWL -7884
G. C. Oberg
W. J. Vanslyke
$K$ R. Price
J. H. Warren
H. P. Shaw
A. T. White
R. M. Smithers
G. T. Stocking
D. D. Woodrich
V. A. Uresk (6)
R. A. Zinsli

44

Battelle-Pacific Northwest Laboratories
E. L. Alpen
W. J. Bair
J. P. Corley
C. E. Cushing (19)
L. L. Eberhardt
R. M. Emery
R. F. Foster
E. L. Klepper

W. H. Rickard

J. A. Strand

W. L. Templeton

B. E. Vaughan

D. G. Watson

W. C. Weimer

R. E. Wildung

Biology Library (3)

Technical Information (5)

Technical Publications (3) 